Original Paper

\title{
Pelatihan Pengembangan Keprofesian Berkelanjutan Bagi Guru Yayasan Pendidikan Pondok Pesantren Yusuf Abdussatar Kediri Lombok Barat
}

\author{
Agus Ramdani $^{1 *}$, L. Muhaimi ${ }^{1}$, Joni Rokhmat ${ }^{1}$ Baehaqi $^{1}$ \\ ${ }^{1}$ Program Studi Magister Administrasi Pendidikan, Universitas Mataram, Indonesia
}

DOI: $10.29303 /$ jpmpi.v2i1.357

Sitasi: Ramdani, A., Muhaimi, L., Rokhmat, J., Baehaqi. (2019). Pelatihan Pengembangan Keprofesian Berkelanjutan Bagi Guru Yayasan Pendidikan Pondok Pesantren Yusuf Abdussatar Kediri Lombok Barat. Jurnal Pengabdian Magister Pendidikan IPA (JPMPI). (2) 1. pp. 71-74

*Corresponding Author: Agus Ramdani, Program Studi Pendidikan Biologi, Fakultas Keguruan dan Ilmu Pendidikan, Universitas Mataram, Indonesia;

Email: aramdani07@unram.ac.id

\begin{abstract}
Kegiatan Pengembangan Keprofesian Berkelanjutan (PKB) merupakan salah satu kegiatan yang dirancang oleh pemerintah untuk mewujudkan terbentuknya guru yang profesional. Permasalahan umum yang dihadapi sekolah/madrasah adalah belum tersosialisasinya konsep PKB dengan baik kepada para guru, termasuk yang dialami oleh guru sekolah mitra yaitu Yayasan Pendidikan Pondok Pesantren Yusuf Abdussatar Kediri Lombok Barat. Tujuan kegiatan pengabdian ini adalah untuk meningkatkan pengetahuan dan keterampilan guru dalam melaksanakan kegiatan PKB termasuk didalamnya penyusunan Publikasi Ilmiah dan Karya Inovatif (PIKI). Pelaksanaan kegiatan pengabdian ini berlangsung dalam tahap: a) Tahap Persiapan, terdiri atas: 1) Koordinasi awal dengan instansi guru sasaran (Yayasan Pendidikan Pondok Pesantren Yusuf Abdussatar Kediri Lombok Barat). 2) Koordinasi dengan Tim Pengabdian Masyarakat (Pembagian tugas), dan 3) Penyusunan materi presentasi dan media latihan). b) Tahap Pelaksanaan, terdiri atas: 1) Koordinasi lanjutan dengan Mitra kegiatan, 2) Pelatihan bagi guru-guru sasaran, 3) Pendampingan penyusunan draf proposal PIKI, 4) Diskusi dan Refleksi terhadap proposal yang telah disusun, dan 5) Perbaikan proposal. c) Tahap Evaluasi dan Pelaporan, terdiri atas: 1) Evaluasi kegiatan dan Rencana tindak lanjut, dan 2) Penyusuna artikel untuk publikasi. Hasil pelatihan yang dilakukan adalah: 1) Guru dapat memperbanyak pengetahuan tentang pengembangan keprofesian berkelanjutan (PKB). 2) Guru dapat meningkatkan layanan pendidikan di sekolah dalam rangka meningkatkan mutu pendidikan. 3) Guru dapat mempercepat proses pembuatan karya tulis ilmiah dalam pengembangan profesi guru. 4) Guru mempunyai keterampilan dalam membuat karya tulis ilmiah dan 5) Guru dapat meningkatkan kualitas penulisan ilmiah sebagai bahan untuk mempersiapakan kenaikan pangkatnya.
\end{abstract}

Kata Kunci: Pengembangan Kepropesian Berkelanjutan; Publikasi Ilmiah; Karya Inovatif.

\section{Pendahuluan}

Dicanangkannya guru sebagai profesi oleh pemerintah berimplikasi pada tuntutan guru ke depan yang semakin berat. Guru dituntut untuk memenuhi kualifikasi dan kompetensi tertentu sehingga mampu mengemban tugasnya secara profesional sesuai dengan jenjangnya. Berdasarkan Undang-Undang Nomor 14 Tahun 2005 tentang Guru dan Dosen dan Peraturan Pemerintah tentang
Standar Nasional Pendidikan, guru dituntut untuk memenuhi kriteria kualifikasi dan kompetensi. Untuk guru pada jenjang pendidikan SMA ke bawah secara kualifikasi diharapkan sekurangkurangnya berpendidikan S1/D4, sementara untuk pengajar di Perguruan Tinggi sekurang-kurangnya berpendidikan S2/magister. Secara kompetensi, guru dituntut memiliki 4 kompetensi, yaitu (1) kompetensi profesional atau akademik, 
kompetensi pedagogis, (3) kompetensi sosial, dan (4) kompetensi kepribadian.

Upaya peningkatan keempat kompetensi tersebut merupakan upaya peningkatan profesionalisme guru. Sebagai konsekuensi dari jabatan guru sebagai profesi, maka diperlukan suatu sistem pembinaan dan pengembangan terhadap profesi guru secara terprogram dan berkelanjutan. Kegiatan Pengembangan Keprofesian Berkelanjutan (PKB) merupakan salah satu kegiatan yang dirancang oleh pemerintah untuk mewujudkan terbentuknya guru yang profesional. Selain itu, sesuai dengan amanat Peraturan Menteri Negara Pemberdayaan Aparatur Negara dan Reformasi Birokrasi Nomor 16 Tahun 2009, tentang Jabatan Fungsional Guru dan Angka Kreditnya, PKB merupakan salah satu unsur utama dalam kenaikan pangkat dan pengembangan karir guru selain kegiatan lainnya yang relevan dengan fungsi sekolah.

Salah satu indikator untuk mengetahui keterlaksanaan kegiatan pengembangan keprofesian berkelanjutan di suatu sekolah/madrasah adalah jumlah guru yang naik pangkat dari waktu ke waktu. Pada kenyataannya, dari hasil observasi di beberapa sekolah/madrasah masih banyak guru berada di golongan IIId dan IVa karena terkendala pada publikasi ilmiah dan karya inovatif yang merupakan bagian dari kegiatan pengembangan keprofesian berkelanjutan. Kondisi seperti ini tentu perlu dicarikan solusinya dengan baik dan inilah yang mendasari Tim Pengabdian Pada Masyarakat Program Studi Magister Administrasi Pendidikan (PS MAP) Unram untuk melakukan kegiatan ini.

Rendahnya publikasi ilmiah dan karya inovatif guru disebabkan oleh belum tersosialisasinya dengan baik tentang program pengembangan keprofesian berkelanjutan yang digagas pemerintah. Disamping itu kemampuan guru dalam menulis karya ilmiah baik itu yang merupakan hasil penelitian maupun hasil kajian pustaka masih perlu ditingkatkan kualitasnya. Berbagai kajian terkait penulisan karya ilmiah termasuk strategi, pendekatan, metode, dan tehnik telah banya dibahas para ahli (Creswell, 2008; Bordens \& Abbott, 2014) Para guru pada umumnya tidak memiliki karya ilmiah penyebabnya adalah kurang terlatih tentang cara menyusun karya ilmiah tersebut. Untuk memperbaiki situasi ini, maka para guru perlu diberikan stimulus yang cukup kuat melalui kegiatan pelatihan dan pendampingan.

Berdasarkan analisis situasi tersebut, maka, dilakukan sebuah kegiatan pengabdian yang berjudul "Pelatihan Pengembangan Keprofesian Berkelanjutan Bagi Guru Yayasan Pendidikan Pondok Pesantren Yusuf Abdussatar Kediri Lombok Barat". Melalui kegiatan ini guru-guru khususnya di sekolah sasaran dapat lebih memahami konsep PKB dan selanjutnya berupaya untuk melaksanakan kegiatan semaksimal mungkin yang dapat meningkatkan profesionalisme sebagaimana diharapkan.

\section{Metode Pelaksanaan}

Pelaksanaan kegiatan pengabdian ini berlangsung dalam beberapa tahap:

a) Tahap Persiapan, terdiri atas: 1) Koordinasi awal dengan instansi guru sasaran (Yayasan Pendidikan Pondok Pesantren Yusuf Abdussatar Kediri Lombok Barat). 2) Koordinasi dengan Tim Pengabdian Masyarakat (Pembagian tugas), dan 3) Penyusunan materi presentasi dan media latihan).

b) Tahap Pelaksanaan, terdiri atas: 1) Koordinasi lanjutan dengan Mitra kegiatan, 2) Pelatihan bagi guru-guru sasaran, 3) Pendampingan penyusunan draf proposal PIKI, 4) Diskusi dan Refleksi terhadap proposal yang telah disusun, dan 5) Perbaikan proposal.

c) Tahap Evaluasi dan Pelaporan, terdiri atas: 1) Evaluasi kegiatan dan Rencana tindak lanjut, dan 2) Penyusuna artikel untuk publikasi

Kegiatan pengabdian ini dimaksudkan untuk meningkatkan profesionalisme guru melalui pelaksanaan kegiatan PKB yang dilakukan oleh para guru sasaran. Terkait dengan hal ini maka sasaran kegiatan ini adalah para guru SMA/MA di Yayasan Pendidikan Pondok Pesantren Yusuf Abdussatar Kediri Lombok Barat yang jumlahnya sebanyak 41 orang. Instansi-instansi yang terkait dengan kegiatan ini adalah, 1) Yayasan Pendidikan Pondok Pesantren Yusuf Abdussatar Kediri Lombok Barat (fungsionaris yayasan telah menyetujui rencana kegiatan ini), 2) Madrasah Aliyah sebagai tempat dan subjek kegiatan pengabdian ini, dan 3) Universitas Mataram sebagai instansi dari tim pengabdian 


\section{Hasil dan Pembahasan}

\section{Analisis Situasi}

Kegiatan tahap pertama dilaksanakan pada hari Selasa 18 September 2018 diisi dengan penyajian materi yang meliputi: 1) Arah kebijakan pengembangan Kabupaten Lombok Tengah (disampaikan oleh Dr. Baehaqi, MM., M.Pd), 2) Penulisan Karya Ilmiah (disampaikan oleh Dr. Lalu Muhaimi ,M.Pd) dan, 3) Penilaian Karya Tulis Ilmiah (disampaikan oleh Dr. Agus Ramdani, M.Sc).

Kegiatan tahap ini diikuti oleh 25 peserta yang terdiri atas guru Yayasan Pendidikan Pondok Pesantren Yusuf Abdussatar Kediri Lombok Barat. Peserta sangat antusias mengikuti kegiatan, terbukti dari munculnya pertanyaan-pertanyaan yang diajukan baik dalam diskusi kelas kepada tim pengabdian pada masyarakat maupun antar sesama peserta dalam aktivitas diskusi kelompok.

Hasil yang diperoleh pada tahap ini memperkuat anggapan yang melatar belakangi pentingnya pengabdian pada masyarakat ini dilakukan yakni Pelatihan Pengembangan Keprofesian Berkelanjutan Bagi Guru Yayasan Pendidikan Pondok Pesantren Yusuf Abdussatar Kediri Lombok Barat. Fakta tentang hal ini terungkap dari proses dan hasil diskusi yang terjadi dalam kelas ketika berlangsungnya sosialisasi.

Hasil kegiatan pengabdian kepada masyarakat dalam bentuk Pelatihan Pengembangan Kepofesian Berkelanjutan bagi guru sangat bermanfaat. Adapun manfaat yang dapat diperoleh dari kegiatan ini adalah: (a) guru dapat memperbanyak pengetahuan tentang pengembangan keprofesian berkelanjutan (PKB), (b) guru dapat meningkatkan layanan pendidikan di sekolah dalam rangka meningkatkan mutu pendidikan, (c) guru dapat mempercepat proses pembuatan karya tulis ilmiah dalam pengembangan profesi bagi guru, (d) guru mempunyai keterampilan dalam membuat karya tulis ilmiah berdasarkan pada pengembangan profesi guru, (e) guru dapat meningkatkan kualitas penulisan ilmiah sebagai bahan untuk mempersiapakan kenaikan pangkatnya.

Hasil kegiatan ini didukung dari hasil kegiatan pengabdian yang dilakukan oleh Rusdarti, dkk, (2018) bahwa hasil akhir adanya pelatihan dan workshop serta pendampingan tentang pengembangan keprofesian berkelanjutan adalah tersusunnya karya tulis ilmiah yang bermutu sesuai kaidah yang ada dalam jurnal ilmiah. Selain itu juga, Dudung (2014) juga menyimpulkan hasil pengabdiannya bahwa guru memiliki keterampilan dalam membuat karya tulis ilmiah berdasarkan pada pengembangan profesi guru.

\section{Hasil Kegiatan}

Berdasarkan hasil pelatihan ddiperoleh hasil yang baik bagi guru. Awalnya, guru belum terbuka wawasannya mengenai pengembangan keprofesian berkelanjutan. Setelah dilakukan pelatihan, guru memiliki kemampuan untuk membuat atau menulis sebuah karya ilmiah yang baik, mengetahui cara publikasi pada jurnal, dan bisa menyusun proposal penelitian terutama penyusunan proposal tindakan kelas. Hal ini mengindikasikan bahwa pelatihan yang diadakan sudah berhasil.

Berdasarkan hasil diskusi, guru sudah memahami bahwa masalah-masalah di dalam proses pembelajaran yang sering mereka alami, bisa dijadikan sebagai karya ilmiah yang selanjutnya bisa dipublikasikan pada Jurnal-Jurnal. Sehingga bisa dikatakan bahwa pelatihan pengembangan keprofesian berkelanjutan (PKB) ini sudah berhasil dengan baik.

\section{Faktor Pendorong dan Penghambat}

Faktor pendorong kegiatan ini adalah kesungguhan guru dalam mengikuti pelatihan, kesediaan Kepala Sekolah untuk menerima Tim melakukan kegiatan pelatihan di sekolah mitra, dan juga pihak terkait yang memprakarsai kegiatan dan membantu menyediaan akomodasi untuk kelancaran pelatihan guru Yayasan Pendidikan Pondok Pesantren Yusuf Abdussatar Kediri Lombok Barat. Semuanya telah menjadikan kegiatan pengabdian ini berjalan sesuai dengan jadwal yang telah ditentukan. Adapun faktor penghambat pelatihan ini dapat dikatakan tidak ada, hanya saja dari segi pendanaan yang menurut Tim masih terbatas, sehingga kegiatan ini hanya memberikan sarana yang terbatas pula, baik kepada guru sebagai peserta pelatihan maupun kepada Tim kegiatan pengabdian ini.

\section{Kesimpulan}

Hasil pelatihan yang dilakukan adalah: 1) Guru dapat memperbanyak pengetahuan tentang pengembangan keprofesian berkelanjutan (PKB). 2) 
Guru dapat meningkatkan layanan pendidikan di sekolah dalam rangka meningkatkan mutu pendidikan. 3) Guru dapat mempercepat proses pembuatan karya tulis ilmiah dalam pengembangan profesi bagi guru. 4) Guru mempunyai keterampilan dalam membuat karya tulis ilmiah berdasarkan pada pengembangan profesi guru. dan 5) Guru dapat meningkatkan kualitas penulisan ilmiah sebagai bahan untuk mempersiapakan kenaikan pangkatnya.

\section{Saran}

Berdasarkan kegiatan pelatihan yang sudah dilakukan, disarankan:

1) Dilakukan pelatihan berlanjut terkait dengan pengembangan keprofesian berkelanjutan.

2) Dilakukan bimbingan berkelanjutan dalam bentuk pembimbingan terstruktur dalam penulisan karya ilmiah oleh Tim.

3) Waktu pelatihan yang terbatas karena mencoba memenuhi kebutuhan perserta tersebut, ada baiknya pada pelatihan selanjutnya berlatih membuat tulisan ilmiah, membuat makalah, jurnal dan proposal mengenai PTK,

4) Dengan sarana, prasana dan pendanaan yang terbatas menyebabkan pada proses pelaksanaan pelatihan ini mengalami sedikit permasalah, namun secara keseluruhan proses pelatihan ini termasuk berhasil dan sukses

\section{Ucapan Terima Kasih}

Tim pengabdian mengucapkan terima kasih kepada Rektor Universitas Mataram yang telah memberikan bantuan dana dan Tim Pengabdian yang bekerjasama dalam menyelesaikan kegiatan ini.

\section{Daftar Pustaka}

Bordens, K., S., and Abbott, B., B., 2014. Research Design and Methods, A Process Approach, ninth edition. New York: McGraw-Hill Education

Creswell, J. W., 2008. Educational Research, planning, conducting, and evaluating quantitative and qualitative research. USA: Pearson Prentice Hall

Dudung, A. 2014. Pelatihan Pengembangan Keprofesian Berkelanjutan (PKB) Bagi Guru-Guru Se Jakarta Timur. Jurnal Sarwahita: Jurnal Pengabdian Kepada Masyarakat. 11(1), DOI: https://doi.org/10.21009/sarwahita.111.03

Kementerian Pendidikan dan Kebudayaan. 2016. Pedoman Kegiatan Pengembangan Keprofesian Berkelanjutan. Jakarta: Dirjen GTK.

Nuh, M., 2010. Petunjuk Teknis Pelaksanaan Jabatan Fungsional Gurudan Angka Kreditnya, Permendiknas no 35. Diknas RI, Kabiro Hukum dan Organisasi

Peraturan Menteri Negara Pemberdayaan Aparatur Negara dan Reformasi Birokrasi Nomor 16 Tahun 2009, tentang Jabatan Fungsional Guru dan Angka Kreditnya

Peraturan Pemerintah Nomor 32 Tahun 2015 tentang Standar Nasional Pendidikan.

Rusdarti, Slamet, A., \& Sucihatiningsih. 2018. Pengembangan Keprofesian Berkelanjutan Dalam Pembuatan Publikasi Ilmiah Melalui Workshop Dan Pendampingan Bagi Guru Sma Kota Semarang. Rekayasa Vol. 16(2).

Undang-Undang RI Nomor14 Tahun 2005 tentang Guru dan Dosen. 